\title{
MENGONTROL EMOSI SISWA DENGAN BANTUAN LAYANAN BIMBINGAN KELOMPOK
}

\author{
Enny Fitriani, Nurasyah \\ Jurusan Bimbingan Konseling, Universitas Muslim Nusantara. \\ Jalan Garu II No. 93, Medan, Sumatera Utara, 20147, Indonesia. \\ E-mail: befhoney_208@ymail.com, Telp: +6285262323418
}

\begin{abstract}
ABSTRAK
Kegiatan pengabdian masyarakat ini bertujuan untuk membantu guru bk dalam meningkatkan pengendalian emosi siswa melalui program layanan bimbingan kelompok agar siswa bisa mengoptimalkan pengembangan potensi dirinya kearah yang lebih positif. Strategi yang ditawarkan dalam kegiatan ini adalah pelatihan program layanan bimbingan kelompok, menyusun desain rencana pelaksanaan layanan (RPL) bimbingan kelompok. Sebagai mitra dalam kegiatan ini adalah SD UNIVA Al Washliyah. Dengan target luaran yakni guru bimbingan konseling mampu membuat program layanan bimbingan kelompok untuk meningkatkan pengendalian emosi siswa sehingga dapat mengembangkan potensi dirinya kearah yang lebih positif.
\end{abstract}

Kata kunci: Bimbingan Kelompok, Etika Komunikasi

\begin{abstract}
This community service activity aims to assist teachers in improving students' emotional control through group guidance services program so that students can optimize their potential development towards a more positive. The strategies offered in this activity are the training of group guidance services program, formulating the design of service implementation plan (RPL) guidance group. As a partner in this activity is SD UNIVA Al Washliyah. With the external target of teachers guidance counseling is able to create a program of guidance services group to improve students' emotional control so as to develop their potential towards a more positive,
\end{abstract}

Key Word: the design of service implementation plan

\section{PENDAHULUAN}

Pada era Globalisasi di masa sekarang ini, arus informasi begitu deras masuk dari berbagai macam media, baik media Televisi, Media Masa dan Internet. Dimana semua manusia tanpa batas usia bebas mengaksesnya tanpa ada filternya. Apalagi dengan adanya internet arus informasi tersebut makin mudah diperoleh sehingga membuat cara pandang siswa kita sedikit demi sedikit berubah meninggalkan cara pandang leluhur kita sebagai orang timur. Hal tersebut memiliki dampak yang besar terhadap perkembangan perilaku siswa.

Berdasarkan hal ini pengendalian emosi pada remaja sangat dibutuhkan agar remaja dapat mencapai kematangan emosi yang optimal. Sobur (2003:400) menekankan bahwa emosi bisa dipikirkan dalam terma-terma apakah ia berkaitan dengan peningkatan efisiensi dan energi yang tersedia untuk berbagai tindakan seperti berfikir, menyerap, berkonsentrasi, memilih, dan bertindak.

Hurlock $1980 \quad$ (Trifiana 2015:29) menjelaskan bahwa peningkatan pengendalian emosi remaja bisa dilihat dari aspekaspek pengendalian emosi yaitu kontrol emosi, penggunaan fungsi kritis mental dan pemahaman diri.

Program Bimbingan Kelompok yang dilaksanakan oleh guru Bimbingan dan Konseling adalah bagian dari Program Bimbingan dan Konseling yang mempunyai fungsi salah satunya adalah faktor 
penghambat terjadinya siswa melakukan perbuatan-perbuatan yang kurang baik.

Di dalam bimbingan tersebut siswa diajak bagaimana mencurahkan permasalah-permasalah yang timbul baik dari rumah, lingkungan sekitar maupun dari sekolah, seperti di SD UNIVA Al Washliyah kurangnya motivasi belajar yang tinggi dan rasa tanggung jawab sebagai siswa hal ini disebab siswa tidak memiliki pengendalian emosi yang baik maka program layanan bimbingan kelompok dapat dimanfaatkan untuk meningkatkan pengendalian emosi siswa sehingga menciptakan subjek didik yang memiliki pribadi yang utuh dan terintegrasi sesuai dengan tujuan esensial pendidikan umum (Shochib, 2000:2).

Sebenarnya emosi yang muncul berawal dari pikiran yang ada di dalam diri siswa hal itu dikarenakan dan disebabkan dirumah tangga artinya ayah atau ibunya dirumah sering marah, membentak, kasar, memaki maka berdampak kepada siswa yang berada di sekolah. Siswa lebih senang bergaul dengan temanteman yang sebayanya dan akhirnya pelariannya adanya perbuatanperbuatan negatif yang dilakukan di sekolah maupun dilingkungan sekitar.Untuk mencegah dari perbuatan yang negatif siswa maka yang harus dilakukan Guru Bimbingan dan Konseling adalah melakukan layanan Bimbingan Kelompok. Tentunya hal tersebut akan menjadi tantangan besar bagi guru bk karena dituntut untuk bisa mengaplikasikan program layanan bimbingan kelompok dengan baik.

$$
\text { Bimbingan kelompok }
$$

dilaksanakan secara berkelompok yang artinya pada waktu dan tempat yang sama diberikan layanan bimbingan kepada sejumlah orang ( siswa ) dengan topik atau materi yang sama. Kelompok dibentuk dengan sejumlah siswa setiap kelompok antara $8-10$ orang dengan tujuan agar siswa dalam kelompok saling berinteraksi atau membahas masalah atau hambatan yang dihadapi dan mencari penyelesaian yang menyebabkan masalah itu timbul. Melalui bimbingan kelompok diharapkan siswa dapat mengendalikan emosinya dan mencari solusi bersama anggota kelompoknya untuk mengatasi masalah pengendalian emosi siswa sehingga siswa akan melakukan halhal yang positif.

\section{METODE PELAKSANAAN}

\section{Tahapan dalam pelaksanaan program layanan bimbingan kelompok untuk meningkatkan pengendalian emosi siswa.}

\section{Tahap pembentukan}

Tahap pembentukan merupakan tahap pengenalan , tahap pelibatan diri atau tahap memasukkan diri kedalam kehidupan kelompok. Pada tahap ini semua anggota saling memperkenalkan diri dan juga mengugkapkan tujuan ataupun harapan-harapan yang ingin di capai baik oleh masing-masing, sebagian maupun seluruh anggota. Kegiatan yang dilakukan pada tahap ini adalah sebagai berikut :

a. Penjelasan pengertian dan tujuan dari bimbingan kelompok

b. Penjelasan cara dan asas bimbingan kelompok 

c. Melaksanakan acara perkenalan antara peserta bimbingan kelompok
d. Menciptakan permainan penghangatan keakraban

\section{Tahap Peralihan}

Tahap peralihan adalah tahapan untuk mengalihkan kegiatan awal kelompok ke kegiatan berikutnya yang lebih terarah pada pencapaian tujuan kelompok. Kegiatan dalam tahap ini adalah sebagai berikut :
a. Masing-masing anggota secara bebas mengemukakan maslah atau topic bahasan
b. Menetapkan masalah atau topik yang akan dibahas terlebih dahulu
c. Anggota membahas masing- masing topik
d. Kegiatan selingan

\section{Tahap Kegiatan}

Tahap kegiatan adalah tahap ketiga yang merupakan inti dari kegiatan kelompok. Kegiatan dalam tahap ini adalah sebagai berikut :
a. Pemimpin kelompok mengemukakan masalah atau topik
b. Tanya jawab antara anggota dan pemimpin kelompok tentang hal-hal yang belum jelas yang menyangkut masalah atau topic yang dikemukakan pemimpin kelompok
c. Anggota membahas masing- masing topik secara mendalam dan tuntas
d. Kegiatan selingan

\section{Tahap Pengakhiran}

Tahap ini merupakan tahap penutup dalam kegiatan bimbingan kelompok. Dalam tahap ini pemimpin kelompok melakukan kegiatan seperti :

a. Pemimpin kelompok mengemukaan bahwa kegiatan akan segera berakhir

b. Meminta kesan dan pesan dari masing-masing anggota kelompok

c. Membahas kegiatan lanjutan

d. Mengemukakan pesan dan harapan

\section{KESIMPULAN DAN SARAN}

\section{A. Kesimpulan}

Pengabdian $\begin{array}{r}\text { masyarakat } \\ \text { meningkatkan pengendalian }\end{array}$
emosi melalui $\begin{array}{r}\text { bimbingan } \\ \text { kelompok di SD UNIVA }\end{array}$
berjalan dengan baik, dengan
kerjasama tim pengabdian yang
sangat solid dan peran serta
aktif dari nara sumber dalam
pengabdian masyarakat ini
berjalan sesuai dengan harapan
dan lancar.

\section{B. Saran}

1. Umumnya untuk pemerintah dan lembaga-lembaga pendidikan formil serta masyarakat diharapakan agar mendukung pelaksanaan program bimbingan konseling agar dapat terlaksana secara maksimal dan sukses untuk peningkatan potensi peserta didik.

2. Khususnya untuk guru bimbingan konseling dharapkan agar meningkatkan kinerjanya sehingga menjadi 
seorang konselor yang
profesional.

\section{DAFTAR PUSTAKA}

Arikunto, Suharsimi, 2006. Prosedur Penelitian Suatu Pendekatan Praktik. Jakarta : Rineka Cipta

Ary Ginajar, 2003, ESQ Power,Jakarta: Arga.

AW. Suranto. 2011. Komunikasi Interpersonal. Yogyakarta. Graha Ilmu

Dawson dalam Triatna dan Kharisma (2008:25) Journal Formatif S(1): 26:41, 2015 ISSN: 208835IX

Goleman (2015) dalan Journal Ilmiah Cisoc Vol II No.2 2016/ISSN 2460-1802

Hartinah, Sitti. 2009. Konsep Dasar Bimbingan Kelompok Bandung: PT Refika Aditama.

Lahmuddin, 2006, Konsep-konsep Dasar Bimbingan dan Konseling, Bandung; Citapustaka Media.

Prayitno, Amti Erman. 2008. Dasardasar Bimbingan dan Konseling. Jakarta: Rineka Cipta.

Prayitno. 2012. Seri Panduan Layanan dan kegiatan Pendukung Konseling. Padang: Universitas Negeri Padang.

Santoso AS. 2008. Modul 10 Kepribadian dan Emosi. Universitas Mercu Buana

Tohirin. 2007. Bimbingan dan Konseling di Sekolah dan Madrasah (Berbasis Integrasi). Jakarta: P. T RajaGrafindo Persada 